\title{
Pembelajaran Pemecahan Masalah dengan Media Interaktif Model Tutorial untuk Meningkatkan Hasil Belajar Matematika Siswa Kelas X Multimedia 3 SMKN 2 Garut Pokok Bahasan Sistem Persamaan Linier Dua Variabel Tahun Pelajaran 2017/2018
}

\author{
Asep Kurnia ${ }^{1}$ \\ SMKN 2 Garut \\ Jl. Suherman No.90, Jati, Kec. Tarogong Kaler, Kabupaten Garut \\ ${ }^{1}$ kurnia2@yahoo.com
}

\begin{abstract}
Abstrak - Penggunaan media dalam kegiatan pembelajaran di kelas dapat mempengaruhi kemampuan pemecahan masalah matematika pada siswa SMK. Salah satu media tersebut adalah media interaktif model tutorial. Dengan media ini siswa lebih bersemangat dalam belajarnya, karena mereka dapat langsung mencari pemecahan masalah matematika yang diberikan oleh gurunya secara interaktif melalui komputer. Hanya dalam pelaksanaannya di kelas, harus dilengkapi dengan sarana yang cukup agar berjalan dengan baik.

Kata kunci - Media Interaktif, Model Tutorial, Hasil belajar, Matematika
\end{abstract}

\section{PENDAHULUAN}

Perkembangan ilmu pengetahuan dan teknologi dewasa ini berkembang sangat pesat. Akibatnya menuntut setiap individu lebih kreatif, memiliki sikap kerja sama yang tinggi, profesional, tanggung jawab, inovatif dan mempunyai kepekaan terhadap masalah yang timbul, serta memiliki kemampuan yang optimal untuk mengatasinya. Untuk menuju individu yang telah disebutkan di atas, salah satunya dapat dibentuk melalui pemberian stimulus melalui sejumlah mata pelajaran yang mendukung. Salah satunya adalah pelajaran matematika. Matematika sebagai salah satu cabang disiplin ilmu pengetahuan memegang peranan penting dalam melatih dan mengembangkan kreatifitas, pola pikir manusia, bahkan sebagai pembentuk sikap. Melalui pembelajaran matematika ini kita mengharapkan pola pikir dan sikap kita, terutama di dalam kehidupan bermasyarakat dapat lebih teratur, sistematis dan efisien. Kita sudah di beri segalanya oleh Alloh SWT secara sempurna baik fisik maupun rohani, tinggal bagaimana kita mensyukurinya.

Sebagaimana Alloh SWT berfirman di dalam Al-Qur'an Surat At-Tin (95: 4) yang artinya, "Sesungguhnya Kami telah menciptakan manusia dalam bentuk yang sebaik-baiknya". Maka sebagai rasa syukur kita kepada-Nya, sudah sepatutnya apa yang ada pada diri kita ini diolah dan dikembangkan sesuai ajaran-Nya, agar tujuan kita berkehidupan masyarakat yang lebih teratur, sistematis dan efisien dapat tercapai. Dalam kaitannya dengan pembelajaran matematika di sekolah, Ruseffendi (2006, h. 94) mengemukakan, "Matematika penting sebagai pembimbing pola berpikir maupun sebagai pembentuk sikap. Oleh sebab itu salah satu tugas guru adalah mendorong siswa agar dapat belajar matematika dengan baik". Namun pada kenyataannya hasil belajar siswa dalam matematika masih rendah, khususnya pada pokok bahasan sistem persamaan linier dua variabel. Hal ini terlihat dari tingkat keberhasilan belajar siswa setelah mengikuti pembelajaran yang masih kurang optimal, bahkan masih jauh dari ekspektasi ketuntasan belajar yang sudah ditetapkan oleh sekolah sebesar $\geq 75$. Dan sebuah kelas dinyatakan sudah tuntas dalam belajarnya jika telah mencapai daya serap ketuntasan klasikal $\geq$ $75 \%$. Data ketuntasan belajar siswa pada pokok bahasan tersebut sekaligus sebagai data awal penelitian ini dapat dilihat pada tabel di bawah :

Tabel 1. Ketuntasan/Hasil Belajar Harian Siswa 
Kelas X Multimedia 1 dan X Multimedia 2

Pokok Bahasan Sistem Persamaan Linier Dua Variabel

Semester Ganjil Tahun Pelajaran 2016/2017

\begin{tabular}{|l|c|c|}
\hline $\begin{array}{c}\text { Ketuntasan } \\
\text { Kelas }\end{array}$ & $\begin{array}{c}\text { Kelas X } \\
\text { MM 1 }\end{array}$ & $\begin{array}{c}\text { Kelas X } \\
\text { MM 2 }\end{array}$ \\
\hline Jumlah Siswa & 34 & 30 \\
\hline Siswa yang tuntas & 22 & 19 \\
\hline $\begin{array}{l}\text { Siswa yang } \\
\text { belum tuntas }\end{array}$ & 12 & 11 \\
\hline $\begin{array}{l}\text { Persentase } \\
\text { Ketuntasan }\end{array}$ & $64,71 \%$ & $63,33 \%$ \\
\hline
\end{tabular}

Dari data di atas jelas bahwa tingkat ketuntasan/keberhasilan belajar siswa dalam matematika masih sangat rendah. Hal ini salah satunya, bisa saja disebabkan oleh kebiasaan guru yang melaksanakan pembelajaran dengan : 1). Hanya memindahkan pengetahuan dari buku ke siswa; 2). Hanya memacu siswa untuk berkompetisi; 3 ). Hanya berbentuk ceramah yang cenderung monoton, kurangnya partisipasi aktif dari siswa. Oleh karena itu guru perlu mengubah bagaimana cara mengajarnya agar siswa lebih semangat dan termotivasi dalam kegiatan pembelajaran. Salah satu bentuk pembelajaran yang sesuai dengan harapan tersebut dengan mengutamakan keaktifan siswa. Seorang pilsuf Yunani mengatakan ; jika mendengar maka akan lupa, jika melihat maka akan mengetahui, dan jika melakukan maka akan memahami. Sehingga jika siswa aktif melakukan pembelajaran, maka diharapkan akan lebih paham tentang materi yang diajarkan.

Banyak bentuk pembelajaran yang dapat diterapkan guru dalam kegiatan belajar mengajar. Pemilihan pembelajaran pemecahan masalah dengan media interaktif model tutorial merupakan cara yang mungkin tepat untuk memotivasi, memberi semangat serta mengembangkan kemampuan intelektual siswa secara optimal. Dengan pembelajaran ini siswa tidak hanya menyerap informasi dari guru, akan tetapi dapat berperan aktif mengembangkan pengetahuannya secara mandiri dengan bimbingan dan arahan guru.

\section{KAJIAN TEORI}

\section{Pembelajaran Pemecahan Masalah dengan Media Interaktif Model Tutorial}

Banyak bentuk pembelajaran yang dapat digunakan guru dalam melaksanakan pembelajaran, salah satu diantaranya adalah bentuk pembelajaran pemecahan masalah. Menurut Sukasno (2002, h. 14) pemecahan masalah adalah suatu proses bagi siswa untuk memecahkan soal-soal atau tugas-tugas yang diberikan kepadanya dengan melibatkan pengetahuan yang sudah dimilikinya. Selanjutnya Ruseffendi (1988, h. 241) menyatakan, "Pemecahan masalah adalah pendekatan yang bersifat umum yang lebih mengutamakan kepada proses daripada hasilnya". Jadi aspek proses sangat penting dalam pembelajaran dengan pendekatan pemecahan masalah, bukannya aspek produk seperti dijumpai pada pembelajaran konvensional. Rendahnya keterampilan berproses akan mempengaruhi hasil belajar siswa di sekolah, khususnya mengenai pemecahan masalah. Dengan menggunakan keterampilan berproses, siswa akan mampu menemukan dan mengembangkan sendiri fakta dan konsep serta menumbuhkan dan mengembangkan sikap dan nilai. Seluruh tindakan dalam proses belajar mengajar akan menciptakan kondisi belajar yang melibatkan siswa aktif. Jadi, pembelajaran pemecahan masalah matematika merupakan upaya guru mendorong dan memfasilitasi siswa dalam mengkonstruksi pemahamannya akan matematika. Keberhasilan guru dalam pembelajaran bukan hanya dilihat dari hasil belajar siswa tetapi juga pada proses dari pembelajaran tersebut.

Untuk mendorong siswa lebih aktif dalam pembelajaran dapat dilakukan dengan berbagai cara. Pada intinya keaktifan itu akan muncul jika ada interaksi antara siswa dengan siswa, maupun siswa dengan guru. Salah satu bentuk pembelajaran yang dapat menginteraksikan siswa multi arah adalah dengan menggunakan media interaktif model tutorial. Multimedia interaktif model tutorial merupakan program pembelajaran individual yang dikemas dalam bentuk pembelajaran berprogram bentuk brancing. Program pembelajaran ini dikembangkan dengan menggunakan software macromedia flash, swash max, director, articulate, dan yang paling familier adalah power point. Multimedia dalam kontek pembelajaran adalah "suatu pemanfaatan komputer untuk membuat dan menggabungkan teks, grafik, audio, gambar bergerak (video dan animasi) dengan menggabungkan link dan tool yang memungkinkan pemakai untuk melakukan navigasi, berinteraksi, bereaksi dan berkomunikasi”.

Sedangkan tutorial secara bahasa adalah "pembelajaran khusus dengan instruktur yang terkualifikasi, dan penggunaan mikro komputer untuk tutorial secara khusus telah mencukupi. Tutorial dengan metode alternatif diantaranya bacaan, demonstrasi, penentuan bacaan atau pengalaman yang membutuhkan respon secara oral dan tulisan serta adanya ujian", (Darmawan, 2011, h. 139). Komputer sebagai tutor berorientasi pada upaya membangun perilaku siswa melalui penggunaan komputer. Secara sederhana polapola pengoperasiannya adalah sebagai berikut :

a. komputer menyajikan materi dengan petunjuk tutorial

b. siswa memberikan respons terhadap soal-soal latihan

c. respons siswa dievaluasi oleh komputer dengan orientasi siswa pada arah siswa dalam menempuh prestasi berikutnya 
d. melanjutkan atau mengulangi tahapan tutorial sebelumnya

Tutorial dalam program pembelajaran dengan bantuan komputer ditujukan sebagai pengganti manusia yang proses pembelajarannya diberikan lewat teks atau grafik pada layar yang menyediakan poin-poin pertanyaan atau permasalahan. Jika respons siswa benar maka komputer akan bergerak pada pembelajaran berikutnya, jika respons siswa salah akan mengulangi pembelajaran sebelumnya atau bergerak pada salah satu bagian tertentu pembelajaran ulang, bergantung pada kesalahan yang dibuat. Metode pembelajaran yang termaktub dalam media interaktif model tutorial harus mengikuti pengajaran secara brancing dimana informasi/mata pelajaran disajikan dalam unit-unit terkecil lalu disusul dengan pertanyaan. Respon siswa dianalisis oleh komputer (diperbandingkan dengan jawaban yang telah diintegrasikan oleh penulis program) dan umpan baliknya yang benar diberikan (Darmawan, 2011). Program ini juga menuntut para siswa untuk mengaplikasikan ide-ide dan pengetahuan yang dimilikinya secara langsung dalam kegiatan pembelajaran di kelas.

\section{PEMBAHASAN}

Ketuntasan Belajar Matematika Siswa Kelas X Multimedia 3 SMKN 2 Garut Tahun Pelajaran 2017/2018 melalui Pembelajaran Pemecahan Masalah dengan Media Interaktif Model Tutorial

Baik guru maupun siswa, pada dasarnya menghendaki ketuntasan/hasil belajar yang optimal dari proses pembelajarannya. Salah satu tolok ukur dari keberhasilan tersebut adalah siswa dapat berpikir matematik secara baik. Jika siswa sudah dapat berpikir matematik dengan baik, maka siswa tersebut dapat meminimalisir kesalahan-kesalahan matematik untuk setiap permasalahan yang diberikan gurunya, terutama pada saat evaluasi penilaian. Keberhasilan berpikir matematik yang baik akan diperoleh dengan seringnya latihan. Latihan yang diberikan kepada siswa harus berdasarkan keterampilan proses. Sehingga perkembangan nalarnya terlatih secara matang, teratur, dan sistematis. Berbeda dengan mereka yang hanya mengutamakan produk, biasanya jarang bertahan lama.

Pembelajaran pemecahan masalah merupakan salah satu solusi untuk membentuk siswa dapat berpikir matematik yang baik. Karena dengan pembelajaran pemecahan masalah siswa dituntut untuk dapat mengembangkan potensi nalarnya secara optimal. Sebagai stimulus respon, maka pada pembelajaran pemecahan masalah ini, siswa di bantu dengan media interaktif model tutorial. Guru hanya sebagai fasilitator dan mediator yang mengarahkan teori, membimbing siswa dalam pembelajaran dan menyusun langkahlangkah strategis dalam proses pemahamannya.
Setelah diberikan tindakan kepada siswa berupa pembelajaran pemecahan masalah matematika di kelas dengan media inetraktif model tutorial, dari siklus I ke siklus II terjadi peningkatan ketuntasan belajar matematika yang besar. Hal ini dapat dilihat dari peningkatan/banyaknya siswa yang berhasil tuntas dalam belajarnya dengan nilai $\geq 75$ dari siklus I ke siklus II. Pada siklus II siswa sudah berhasil mencapai kriteria yang diharapkan yaitu minimal $75 \%$ dari seluruh siswa di kelas X Multimedia 3 SMKN 2 Garut tahun pelajaran $2017 / 2018$ yang mencapai nilai $\geq 75$. Oleh karena ketuntasannya sudah memenuhi kriteria yang diharapkan, maka penelitian tindakan kelas ini berakhir hanya sampai siklus II. Demikian pun untuk aktivitas siswa dan guru, setelah diberikan review dan saran oleh observer, peneliti langsung menindaklanjutinya pada siklus berikutnya sehingga terlihat perubahan pada diri siswa maupun guru.

Adapun hasil yang diperoleh dari penelitian tindakan kelas ini adalah :

1. Pada Siklus I

1.1. Ketuntasan Belajar dan Rata-rata Penguasaan Siswa

Pada siklus I, ketuntasan belajar siswa masih rendah, bahkan lebih rendah dari data awal pada tahun sebelumnya, yaitu hanya sebesar 44,12\%. Hal ini besar kemungkinan disebabkan oleh belum terbiasanya siswa dengan pembelajaran pemecahan masalah. Sehingga mereka agak lambat untuk memahami berbagai persoalan pemecahan masalah dalam pokok bahasan sistem persamaan linier dua variabel ini. Sedangkan rata-rata tingkat penguasaannya sebesar $63 \%$. Rata-rata tingkat penguasaan ini merupakan seberapa besar siswa memahami materi yang diajarkan oleh guru sehingga ia dapat menyelesaikan persoalan pemecahan masalah dengan benar.

1.2. Aktivitas Belajar Siswa

Pada siklus I, aktivitas siswa selama pembelajaran pemecahan masalah berada pada kategori cukup yaitu sebesar $64,17 \%$. Aktivitas siswa di siklus I ini masih agak kaku, dikarenakan belum beradaptasi dengan pembelajaran pemecahan masalah dengan memakai media interaktif model tutorial. Namun Sebagian besar siswa cukup antusias dengan pembelajaran yang dilaksanakan, cukup tanggap terhadap pertanyaan dan permasalahan yang diajukan guru, serta siswa sudah cukup berani untuk bertanya atau mengemukakan pendapat.

\subsection{Aktivitas Guru}

Pada siklus I, guru sudah cukup baik melaksanakan pembelajaran pemecahan 
masalah dengan media interaktif model tutorial. Guru menyampaikan tujuan pembelajaran, mengadakan apersepsi dan mengajukan permasalahan. Kemudian siswa dibimbing dan diarahkan tentang cara berdiskusi yang benar tentang penyelesaian setiap persoalan yang diberikan guru dengan metode eliminasi dan substitusi. Dalam mengatur dan mengamati kegiatan siswa, guru berkeliling ke tiap-tiap kelompok sambil memberikan arahan, bimbingan, dan motivasi dengan cara yang positif. Akhir dari aktivitas guru dalam menutup pelajaran yaitu bersama dengan siswa menyimpulkan materi pelajaran dan memberikan tindak lanjut berupa pekerjaan rumah atau PR.

\section{Pada Siklus II}

2.1. Ketuntasan Belajar dan Rata-rata Penguasaan Siswa

Pada siklus II, ketuntasan belajar siswa meningkat sangat baik dari siklus sebelumnya, yaitu dari $44,12 \%$ menjadi $76,47 \%$. Salah satu hal yang menyebabkan ini adalah siswa mulai terbiasa dengan pembelajaran pemecahan masalah. Sehingga mereka dengan penuh semangat dan motivasi belajar yang tinggi sangat antusias dalam belajar. Apalagi secara interaktif siswa dapat mencobakan penyelesaian yang sudah mereka lakukan pada komputer (laptop). Demikian pula untuk ratarata tingkat penguasaannya, meningkat dari $63 \%$ pada siklus I menjadi $73,47 \%$ pada siklus II. Artinya penguasaan materi oleh siswa untuk pokok bahasan ini mengalami peningkatan yang baik.

2.2. Aktivitas Belajar Siswa

Pada siklus II, aktivitas siswa selama pembelajaran pemecahan masalah sudah berada pada kategori baik yaitu sebesar $77,1 \%$. Artinya pada siklus II ini mereka sangat antusias, bersemangat dan termotivasi terutama ketika mencobakan penyelesaiannya pada komputer (laptop). Antusiasme siswa ini ditunjukan pula dengan cukup tanggapnya terhadap pertanyaan dan permasalahan yang diajukan guru, serta siswa sudah berani untuk bertanya atau mengemukakan pendapat.

2.3. Aktivitas Guru

Pada siklus II, guru sudah semakin baik melaksanakan pembelajaran pemecahan masalah dengan media interaktif model tutorial. Guru menyampaikan tujuan pembelajaran, mengadakan apersepsi dan mengajukan permasalahan. Kemudian siswa dibimbing dan diarahkan tentang cara berdiskusi dan menentukan penyelesaian yang benar dengan metode determinan. Dalam mengatur dan mengamati kegiatan siswa, guru berkeliling ke tiap-tiap kelompok sambil memberikan arahan, bimbingan, dan motivasi dengan cara yang positif. Akhir dari aktivitas guru dalam menutup pelajaran yaitu bersama dengan siswa menyimpulkan materi pelajaran dan memberikan tindak lanjut berupa pekerjaan rumah atau PR.

Secara garis besarnya hasil penelitian tindakan kelas pembelajaran pemecahan masalah dengan media interaktif model tutorial di kelas X Multimedia 3 SMKN 2 Garut tahun pelajaran 2017/2018 dapat dilihat pada tabel berikut :

\section{Tabel 2 Rekapitulasi Hasil Ketuntasan dan Rata-rata Penguasaan Belajar Siswa}

\begin{tabular}{|l|c|c|c|c|}
\hline $\begin{array}{l}\text { Keberhasila } \\
\text { n dan } \\
\begin{array}{c}\text { Penguasaan } \\
\text { Belajar } \\
\text { Siswa }\end{array}\end{array}$ & \multicolumn{2}{|c|}{ Siklus I } & \multicolumn{2}{c|}{ Siklus II } \\
\cline { 2 - 5 } & Jml & \% & Jml & \% \\
\hline $\begin{array}{l}\text { Siswa } \\
\text { Tuntas }\end{array}$ & 15 & 44,12 & 26 & 76,47 \\
\hline $\begin{array}{l}\text { Siswa } \\
\text { Belum } \\
\text { Tuntas }\end{array}$ & 19 & 55,88 & 8 & 23,53 \\
\hline $\begin{array}{l}\text { Rata-rata } \\
\text { Penguasaan } \\
\text { Belajar } \\
\text { Siswa }\end{array}$ & \multicolumn{2}{|c|}{63} & \multicolumn{2}{|c}{73,47} \\
\hline
\end{tabular}

\section{Tabel 3 Rekapitulasi Keaktifan Belajar Siswa dan Aktivitas Guru dalam Pembelajaran}

\begin{tabular}{|l|c|c|c|c|}
\hline $\begin{array}{c}\text { Kegiata } \\
\text { n }\end{array}$ & $\begin{array}{c}\text { Sik } \\
\text { lus } \\
\text { I }\end{array}$ & $\begin{array}{c}\text { Kat } \\
\text { ego } \\
\text { ri }\end{array}$ & $\begin{array}{c}\text { Sikl } \\
\text { us } \\
\text { II }\end{array}$ & $\begin{array}{c}\text { Kate } \\
\text { gori }\end{array}$ \\
\hline Aktivita & $\begin{array}{c}64, \\
\text { s Siswa }\end{array}$ & $\begin{array}{c}\text { Cuk } \\
\%\end{array}$ & $\begin{array}{c}77,1 \\
\text { up }\end{array}$ & Baik \\
s Aktivita & B & $\begin{array}{c}\text { Bai } \\
\text { k }\end{array}$ & B & Baik \\
\hline s Guru & &
\end{tabular}

\section{KESIMPULAN}

Pembelajaran pemecahan masalah dengan media interaktif model tutorial di kelas X Multimedia 3 SMKN 2 Garut tahun pelajaran 2017/2018 sangat berpengaruh positif terhadap ketuntasan/hasil belajar matematika siswa pokok bahasan sistem persamaan linier dua variabel. Pengaruh positif juga terlihat pada kenaikan rata-rata penguasaan siswa terhadap materi tersebut, serta aktivitas, motivasi, semangat dan antusiasme siwa. 
Pembelajaran pemecahan masalah dengan media interaktif model tutorial sebagai salah satu bentuk pembelajaran matematika yang inovatif, amatlah layak jika dijadikan salah satu alternatif bagi guru untuk melaksanakan pembelajaran matematika di kelas. Mengingat pembelajaran ini secara langsung dapat membantu meningkatkan ketuntasan/hasil belajar matematika siswa X Multimedia 3 SMKN 2 Garut tahun pelajaran 2017/2018.

\section{DAFTAR PUSTAKA}

[1] Arikunto, S. (1999). Dasar-dasar Evaluasi Pendidikan. Jakarta : Rineka Cipta

[12] Arikunto, S. (1996). Prosedur Penelitian Suatu Pendekatan Praktek. Jakarta : Rineka Cipta

[3] Dahar, R. W. (1996). Teori-teori Belajar. Jakarta : Erlangga

[4] Darmawan, D. (2011). Teknologi Pembelajaran Cetakan ke-1. Bandung: PT Remaja Rosdakarya.

[4] Depdiknas (2006). Permendiknas No. 22 tahun 2006. Jakarta : Depdiknas

[5] Harry (1982). Faktor-faktor yang Mempengaruhi Prestasi belajar. Bandung : IKIP Bandung

[6] Hudoyo, H. (1979). Pengembangan Kurikulum Matematika dan Pelaksanaannya di Depan Kelas. Surabaya : Usaha Nasional

[7] Hudoyo, H. (2003). Pengembangan Kurikulum dan Pembelajaran Matematika. Malang : JICA IKIP Malang

[8] Humaini (2007). Implementasi Pembelajaran Kooperatif Tipe Team Games Tournament (TGT) untuk Pokok Bahasan Bilangan Pecahan pada Siswa SMPN 1 Rantau Badauh. http :llwww.google.co.id.

[9] Kadir, A. (2000). Suatu Alternatif Pembelajaran untuk Meningkatkan Kemampuan Problem Matematika pada Siswa Madrasah Aliyah. Tesis PPS UPI Bandung : Tidak diterbitkan

[10] Kisworo, A. (2000). Pembelajaran Pemecahan Masalah pada Pembelajaran Geometri di Kelas I Smu Petra Surabaya. Tesis PPS Universitas Negeri Surabaya : Tidak Diterbitkan

[11] Lestari, T. (1997). Dampak Metode Pemecahan Masalah terhaddap Kemampuan Berpikir Siswa dalam Pengajaran Matematika (Tesis). Bandung : PPS UPI Bandung

[12] Nasution (1986). Psikologi Pendidikan. Jakarta : Departemen $\mathrm{P} \& \mathrm{~K}$

[13] Ruseffendi (1988). Pengantar kepada Membantu Guru Mengembangkan Kompetensinya dalam Pengajaran Matematika untuk Meningkatkan CBSA. Bandung : Tarsito

[14] Ruseffendi (1991). Pengantar kepada Membantu Guru Mengembangkan Kompetensinya dalam Pengajaran Matematika untuk Meningkatkan CBSA. Bandung : Tarsito

[15] Ruseffendi (1998). Dasar-dasar Penelitian Pendidikan dan Bidang Non-Eksakta Lainnya. Semarang : IKIP Semarang Press
[16] Sabandar, J. (2001). Aspek Kontekstual dalam Soal Matematika dalam Realistic Mathematics Education. Makalah Disajikan pada Seminar Sehari "Realistic Mathematics Education” di Kampus UPI Bandung. Bandung : UPI Bandung

[17] Slavin, R. E. (1997). Cooperative Learning Theory, Research and Practise (Second Edition). Massachusetts : Allyin and Bacon Publishers.

[18] Soedjadi, R. (1992). Simplikasi Beberapa Konsep dalam Matematika untuk Matematika Sekolah dan Dampaknya. (Suatu analisis Komparatif). Surabaya : IKIP Surabaya

[19] Soedjadi, R. (1994). Memantapkan Matematika Sekolah sebagai Wahana Pendidikan dan Pembudayaan Penalaran. (Makalah Seminar) tidak diterbitkan

[20] Soedjadi, R. (1999). Kiat Pendidikan Matematika di Indonesia. Jakarta : Depdiknas

[21] Sudjana (1989). Dasar-dasar Proses Belajar Mengajar. Bandung : Sinar Baru

[22] Sudjana (1996). Metode Statistika. Bandung : Tarsito

[23] Sudjimat, D. A. (1996). Pembelajaran Pemecahan Masalah : Tinjauan Singkat Berdasar Teori Kognitif. Jurnal Pendidikan Humaniora dan Sains. Malang : IKIP Malang

[24] Suherman, E. dan Sukjaya, Y. (1990). Petunjuk Praktis untuk Melaksanakan Evaluasi Pendidikan Matematika. Bandung : Wijayakusumah

[25] Suherman, dkk. (2001). Strategi Pembelajaran Matematika Kontemporer. Bandung : JICA UPI Bandung

[26] Sukasno (2002). Model Pembelajaran Pemecahan Masalah dalam Pembelajaran Trigonometri (Tesis). Bandung : UPI Bandung Tidak diterbitkan

[27] Sumarmo, U. (1994). Suatu Alternatif Pengajaran untuk Meningkatkan Kemampuan Pemecahan Masalah pada Guru dan Siswa SMA di Kodya Bandung. Laporan Penelitian IKIP Bandung : Tidak diterbitkan

[28] Sumarmo, U. (2000). Kecenderungan Pembelajaran Matematika pada Abad 21. Makalah Lokakarya. Tidak diterbitkan

[29] Suparno, P. (1997). Pedoman Pelaksanaan Penelitian Tindakan Kelas (PTK) : Pemantauan dan Evaluasi. Yogyakarta : Dirjendikti Depdikbud

[30] Sutiarso (2000). Problem Posing : Strategi Efektif Meningkatkan Aktivitas Siswa dalam Pembelajaran Siswa. Prosiding konferensi Nasional Matematika X. Majalah Ilmiah Himpunan Matematika Indonesia. Bandung : Institut Teknologi Bandung

[31] Suwarkono (2004). Penilaian Pembelajaran Matematika Pada Kurikulum 2004 (Makalah). Jakarta : LPMP DKI Jakarta

[32] Wheatley, G. H. (1991). Mathematics Learning. Journal Constructivist Perspective on Science and of Science Education. Disertasi PPS IKIP Bandung : tidak diterbitkan

[33] Winkel, Ws. (1991). Psikologi Pendidikan \& Evaluasi Belajar. Jakarta : PT. Gramedia 
